\title{
Review \\ Gene Mapping, Cloning and Association Analysis for Salt Tolerance in Rice
}

\author{
Xiaoru Fan ${ }^{1} \mathbb{0}$, Hongzhen Jiang ${ }^{2}$, Lijun Meng ${ }^{3,4, *}$ and Jingguang Chen ${ }^{2, *}$ \\ 1 School of Chemistry and Life Science, Anshan Normal University, Anshan 114007, China; \\ 2017203043@njau.edu.cn \\ 2 School of Agriculture, Shenzhen Campus of Sun Yat-sen University, Shenzhen 518107, China; \\ jianghzh23@mail.sysu.edu.cn \\ 3 Shenzhen Branch, Guangdong Laboratory of Lingnan Modern Agriculture, Genome Analysis Laboratory of \\ the Ministry of Agriculture and Rural Affairs, Agricultural Genomics Institute at Shenzhen, Chinese \\ Academy of Agricultural Sciences, Shenzhen 518120, China \\ 4 Kunpeng Institute of Modern Agriculture at Foshan, Foshan 528200, China \\ * Correspondence: menglijun@caas.cn (L.M.); chenjg28@mail.sysu.edu.cn (J.C.)
}

Citation: Fan, X.; Jiang, H.; Meng, L.; Chen, J. Gene Mapping, Cloning and Association Analysis for Salt

Tolerance in Rice. Int. J. Mol. Sci. 2021, 22, 11674. https://doi.org/10.3390/ ijms222111674

\section{Academic Editors:}

Mirza Hasanuzzaman and

Masayuki Fujita

Received: 10 October 2021

Accepted: 27 October 2021

Published: 28 October 2021

Publisher's Note: MDPI stays neutral with regard to jurisdictional claims in published maps and institutional affiliations.

Copyright: (c) 2021 by the authors. Licensee MDPI, Basel, Switzerland. This article is an open access article distributed under the terms and conditions of the Creative Commons Attribution (CC BY) license (https:/ / creativecommons.org/licenses/by/ $4.0 /)$.

\begin{abstract}
Soil salinization caused by the accumulation of sodium can decrease rice yield and quality. Identification of rice salt tolerance genes and their molecular mechanisms could help breeders genetically improve salt tolerance. We studied QTL mapping of populations for rice salt tolerance, period and method of salt tolerance identification, salt tolerance evaluation parameters, identification of salt tolerance QTLs, and fine-mapping and map cloning of salt tolerance QTLs. We discuss our findings as they relate to other genetic studies of salt tolerance association.
\end{abstract}

Keywords: salt tolerance; quantitative trait locus (QTL); association analysis; marker-assisted selection (MAS); rice (Oryza sativa L.)

\section{Introduction}

Land clearing, excessive irrigation, salt intrusion into coastal zones and sea-level rise has increased soil salinity, and this is now a significant abiotic stress affecting crop production and quality [1]. A total of $6 \%$ of the world's land area and $20 \%$ of irrigated agriculture have been affected by soil salinity. Salinity also poses a serious threat to irrigated agriculture [2,3]. The salinity problem in crop production will likely worsen due to the increasing human population [4].

Rice (Oryza sativa L.) is a staple food for much of the global population [4,5]. Rice is a salt-sensitive crop and yield can be greatly reduced (by over 50\%) when soil salinity exceeds $6 \mathrm{dS} / \mathrm{m}$ [6]. Salt tolerance in rice varies as the growth stage does. Rice is salt-sensitive at the seedling stage, moderately salt-tolerant at the vegetative stage, and highly sensitive at the reproductive stage [7].

Salt tolerance in rice is controlled by multiple physiological and biochemical reactions, including osmotic stress and ionic stress [3]. Therefore, it is difficult to improve the salt tolerance of rice using traditional breeding methods [7]. Marker-assisted selection (MAS) and genetic engineering technology can accelerate the process of selecting for salt-tolerant rice varieties, but it is difficult to obtain salt-tolerant varieties for crop production by the insertion of single genes [8]. Therefore, it is necessary to simultaneously introduce multiple key genes to improve many pathways in the salt-tolerant regulatory network [8]. It is important to understand the molecular mechanisms and to identify the quantitative trait loci (QTL) and key genes of rice salt tolerance $[1,9,10]$.

Genome-wide QTL analysis has been used to identify salt tolerance-related sites, and this has identified many QTLs related to rice salt tolerance. These studies have provided a foundation for the cloning of salt tolerance genes. The location and cloning of salttolerant genes, or QTLs, have promoted molecular-assisted selection breeding in rice. This 
review summarizes research on rice salt tolerance gene mapping, cloning, and breeding applications to aid breeding of salt-tolerant varieties.

\section{QTL Analysis of Salt Tolerance in Rice}

\subsection{QTL Mapping Population for Salt Tolerance}

Mapping QTLs provides insights in the inheritance mechanisms of the quantitative traits in plants and animals [11]. The mapping populations used for QTL analysis could be divided into permanent populations and temporary populations [11]. In the QTL analysis of salt tolerance in rice, the permanent populations included recombinant inbred lines (RILs) and introgression lines (ILs). RIL population-parent combinations included Kolajoha $\times$ Ranjit [12], Jiucaiqing $\times$ IR26 [13,14], Changbai10 $\times$ Dongnong425 [15], Tesanai 2×CB, (Nona Bokra $\times$ Pokkali) $\times($ IR4630-22-2-5-1-3 $\times$ IR10167-129-3-4) [16], IR4630 $\times$ IR15324 [17], Co39 $\times$ Moroberekan [18], Milyang23 $\times$ Gihobyeo [19,20], H359 $\times$ Acc8558 [21], IR29 $\times$ Pokkali B [22], Yiai1 $\times$ Lishuinuo [23], CSR11 ×MI48 [24], CSR27 $\times$ MI48 [25], and Dongxiang $\times$ NJ16 [7]. IL population-parent combinations included IR64 $\times$ Tarom Molaii [26], Ilpumbyeo $\times$ Moroberekan [27], Minghui86×ZDZ057, Minghui86 $\times$ Teqing Shuhui527 $\times$ ZDZ057, Shuhui527 $\times$ Teqing [28], Lemont $\times$ Teqing [29], Pokkali $\times$ IR29 [30,31], Teqing $\times$ Oryza rufipogon [32], Ce258 $\times$ IR758 62 [33], Tarome-Molaei $\times$ Tiqing [34], Xiushui $09 \times$ IR2061 [35], IR64 $\times$ Binam [36], and Nipponbare $\times$ Kasalath [37]. In addition, there are doubled haploid (DH) groups that include IR64 $\times$ Aucena [38] and Zhaiyeqing $8 \times$ Jingxi 17 [39,40]. Some studies also used a set of chromosome segment substitution lines (CSSLs) to detect salt tolerance in seedlings [41]. Mapped salt-tolerant QTLs that have permanent populations could analyze phenotypic variation at multiple points over multiple years. In this way, the identified salt-tolerant QTLs are more stable and not affected by the environment, which was of benefit to map-based cloning and molecular breeding applications. However, most of the permanent populations in the studies were not used for salt tolerance analysis. There was a lack of highly salt-tolerant or salt-sensitive parental varieties. The salt tolerance difference between the parents was small, which was not conducive to the identification of major salt-tolerant sites. Only a few populations were constructed that had salt-tolerant varieties as their parents and used for salt tolerance research, such as Kolajoha $\times$ Ranjit [12], Jiucaiqing $\times$ IR26 [13,14], $($ Nona Bokra $\times$ Pokkali) $\times($ IR4630-22-2-5-1-3 $\times$ IR10167-129-3-4) [16], IR29 $\times$ Pokkali [22], CSR11 $\times$ MI48 [24], and CSR27 $\times$ MI48 [25].

Most of the salt-tolerant QTL mapping of rice has used temporary populations. Most of these populations were $\mathrm{F}_{2}$ and $\mathrm{F}_{3}$ populations, and a few were $\mathrm{F}_{4}, \mathrm{BC}_{1} \mathrm{~F}_{1}, \mathrm{BC}_{1} \mathrm{~F}_{2: 3}$, and $\mathrm{BC}_{2} \mathrm{~F}_{2: 3}$ populations. The parent populations included Gharib $\times$ Sepidroud [42,43], Nona Bokra $\times$ Koshihikari [44], Tarommahali $\times$ Khazar [45,46], Pokkali $\times$ Shaheen Basmati [47], BRRI Dhan40 $\times$ IR61920-3B-22-2-1 [48], Dongnong425 $\times$ Changbai10 [15,49], Jiucaiqing $\times$ IR36 [50], Sadri $\times$ FL478 [51], NERICA-L-19 $\times$ Hasawi, Sahel 108 $\times$ Hasawi, and BG90-2 $\times$ Hasawi [52], IR36 $\times$ Pokkali [53,54], CSR27 $\times$ MI48 [55], Cheriviruppu $\times$ Pusa Basmati1 [56], and Peta $\times$ Pokkali [57]. These populations were used for QTL analysis of salt-tolerant materials such as Gharib, Nona Bokra, Tarommahali, Pokkali, Jiucaiqing, FL478, Hasawi, IR61920-3B-22-2-1, Cheriviruppu, Changbai10, and CSR27 [42-52,55,56].

Some studies used two or more populations simultaneously for salt tolerance QTL analysis. Tiwari et al. [24] identified the salt-tolerant QTLs that had two RIL populations CSR11 $\times$ MI48 and CSR27 $\times$ MI48; Cheng et al. and Yang et al. [29,35] used the two-way combination of Xiushui09 $\times$ IR2061 and Lemont $\times$ Teqing; Qian et al. [28] selected Shuhui 527 $\times$ ZDZ057, Minghui $86 \times$ ZDZ057, Shuhui 527 $\times$ teqing, and Minghui $86 \times$ teqing for salt tolerance QTL analysis; Sun et al. [49] used $\mathrm{F}_{3}$ and $\mathrm{BC}_{1} \mathrm{~F}_{2: 3}$ populations of Dongnong $425 \times$ Changbai 10 to analyze the dynamic QTL that controls the ion content in rice roots; Bimpong et al. [52] used $F_{2}$ populations of NERICA-L- $19 \times$ Hasawi, Sahel $108 \times$ Hasawi and BG90-2 $\times$ Hasawi to identify QTLs for salt tolerance in Hasawi. QTL analysis and 
comparison with multiple mapped populations were conducive to finding salt-tolerant sites that could be stably expressed and less affected by genetic background.

\subsection{Period and Method of Salt Tolerance Identification}

Rice has different tolerances to salt stress at different growth stages [7]. The seedling stage and the reproductive growth stage are salt-sensitive, while the seed germination stage and the vegetative growth stage are more salt-tolerant [7]. Therefore, most of the studies of salt tolerance QTL analysis in rice have been conducted during the seedling and reproductive growth stages [58].

More than half of the QTL studies on rice salt tolerance have used the seedling stage. The methods used for the identification of salt tolerance at the seedling stage were uniform. Rice seedlings were cultivated by hydroponics, and treated with salt at, or near, the threeleaf stage $[13,14,16,17,19-23,26,28-30,34-36,40,43-46]$. For the reproductive growth stage, most rice studies used plants in artificial salt ponds. A small number of studies used rice planted in soil and treated with salt water $[24,25,40,51-56]$. The initial and final salt treatments were different in different studies. Most of the studies transplanted rice to salt ponds in the seedling or tillering stage, where they were grown to maturity. The plants were then scored for agronomic traits and physiological indicators of salt tolerance $[24,25,40,51-54,57]$. A few studies analyzed salt tolerance QTL in the seed germination stage, and conducted the germination in a medium with salt as a treatment [13,38,42].

Some studies simultaneously analyzed salt tolerance QTL in two or more growth and development stages. Gu et al. and Pandit et al. [25,57] identified the salt tolerance QTL in the vegetative and reproductive growth stages of rice; Zang et al. [36] identified tolerance in the seedling stage and vegetative growth stage; Ammar et al. [55] analyzed salt tolerance QTLs in seedling, vegetative growth, and reproductive growth stages. These studies helped to identify the genes that control salt tolerance in multiple growth and development stages of rice.

To analyze the influence of plant developmental differences on salt tolerance, some studies used a control group. They analyzed the salt tolerance of the mapping population under the salt and the control treatments at the same time $[13,14,24,27,28,36-38,40,49,52-54,57]$. Most of the studies used permanent populations that are homozygous for each strain. A few studies used different tillers from $\mathrm{F}_{2}$ populations for different treatments.

\subsection{Salt Tolerance Evaluation Parameter}

The salt tolerance of rice is a complex and comprehensive trait that has various evaluations that differ between development stages. In QTL analysis of rice salt tolerance, the evaluation parameters at the seedling stage can be divided into three categories: morphological, growth and physiological. Morphological parameter analysis evaluates the salt tolerance of the seedlings (score of salt tolerance, SST) by observing the blade tips, leaves, tillers, and the growth inhibition and death of plants after salt stress, and also investigating the survival days of seedling (SDS) after salt stress $[14,15,18-20,22,23,26-$ 30,33,35,36,43,44,46-48,55,59]. Most studies have used the standard evaluation system (SES) proposed by the International Rice Research Institute (IRRI) to evaluate the salt damage level [60]. Some studies modified the evaluation criteria based on experimental materials and experimental design $[19,22,26,28-30,33,35,36,43,46,47,55,59]$. The growth indicators used to evaluate the salt tolerance during the seedling stage include plant height and the fresh and dry weight of shoots and roots $[14,17,22,27,43,45-47]$. There are many physiological parameters for evaluating the salt tolerance of rice, and the indicators for QTL analysis include plant ion content, the concentration of shoot $\mathrm{Na}^{+}(\mathrm{SNC})$ and $\mathrm{K}^{+}$ (SKC), shoot $\mathrm{Na}^{+} / \mathrm{K}^{+}$ratio (SNKR), the concentrations of root $\mathrm{Na}^{+}(\mathrm{RNC})$ and $\mathrm{K}^{+}$content (RKC), and root $\mathrm{Na}^{+} / \mathrm{K}^{+}$ratio (RNKR) [14-17,21,22,26,29,33-35,43-47,59]. Some studies also analyzed QTL with the chlorophyll content of seedlings after salt stress [22,43,45].

The evaluation parameters for the salt tolerance of rice seeds during germination include germination rate and germination vigor. Some studies further analyzed growth 
of the embryo and the radicle of seedlings after germination [13,38,42]. The evaluation parameters during the vegetative growth stage included plant growth and physiological indicators. Most studies analyzed the growth and ion content of the shoot rather than the root $[18,25,36,49,50,55,57]$. The evaluation during reproductive growth included yield-related agronomic traits, such as the heading date, plant height, tiller number panicles per plant, grains per panicle, seed setting rate, 1000-seed weight, and yield per plant $[24,25,40,51,52,55-57]$. Some studies analyzed the content of $\mathrm{Na}^{+}, \mathrm{K}^{+}, \mathrm{Ca}^{2+}$, and $\mathrm{Cl}^{-}$ in rice leaves or straw after salt treatment in the reproductive growth stage $[25,51,53,55]$. Some studies included control groups, and they used the absolute value of each evaluation parameter for QTL analysis between the control and comparison groups. They also used the relative value of each salt tolerance trait (treatment/control) or decrease rate ((control-treatment)/control) as an indicator, which was beneficial in reducing the influence of individual plant differences $[24,27,49,53,54,57]$.

\subsection{Salt Tolerance QTL}

We found 52 salt tolerance QTL studies in rice, as shown in Table 1. More than half of the salt-tolerant QTLs were in the seedling stage. Salt-tolerant QTLs at each growth stage were distributed on the 12 rice chromosomes.

The phenotypic contribution rate of a single QTL ranged from $0.02 \%$ to $81.56 \%$. A total of 167 QTLs had a contribution greater than $20 \%$ and these occupied $22.0 \%$ of the total QTLs (Table 1). Salt-tolerant QTLs that have a large contribution to the phenotype were found in the studies that follow. Thomson et al. [22] detected 16 salt-tolerant QTLs which explained more than $20 \%$ of the phenotypic variation in the seedling stage. Of these, five QTLs had a contribution exceeding 50\%. Qian et al. [28] used four mapping populations and detected 43 QTLs that control SST or SDS in seedlings. The contributions of 12 QTLs were more than $20 \%$. Sabouri et al. [45] identified 32 QTLs that control different growth and physiological indicators of salt tolerance in rice seedlings. Among them, 14 QTLs explained more than $20 \%$ of the phenotypic variation. Bimpong et al. [52] detected 75 salt tolerance QTLs in three mapping populations during the reproductive stage, of which about half of the QTLs (37) explained more than $20 \%$ of the phenotypic variation. Ammar et al. [55] detected 25 QTLs that had a contribution greater than $10 \%$ in the seedling, vegetative growth, or reproductive growth stage, and 22 QTLs among these had a contribution rate over $20 \%$. In these studies, there were 101 salt-tolerant QTLs that had a phenotypic contribution rate exceeding $20 \%$. There were only a few QTLs that had large effects in other studies, and 13 studies had no salt-tolerant QTLs that exceeded a $20 \%$ variation. $[5,15,17,25,27,30,33,38,47,50,59,61,62]$. 
Table 1. Identified QTL for salt tolerance in rice.

\begin{tabular}{|c|c|c|c|c|c|c|c|}
\hline Stage & Parents for Cross & Population Type & Evaluation Parameter for Salt Tolerance & PVE \% & QTL & High-PVE QTL & Reference \\
\hline \multirow{4}{*}{ Germination stage } & IR64×Azucena & DH & $\begin{array}{l}\text { GR, seedling root length, seedling dry mass, } \\
\text { seedling vigor }\end{array}$ & $13.5-19.5$ & 7 & 0 & [38] \\
\hline & Jiucaiqing $\times$ IR26 & RIL & GR, RL, $\mathrm{SH}$ & $6.5-43.7$ & 7 & 4 & [13] \\
\hline & Gharib $\times$ Sepidroud & $\mathrm{F}_{2} / \mathrm{F}_{2: 4}$ & $\begin{array}{l}\text { GR, germination percentage, radicle length, } \\
\text { plumule length, coleoptile length, radicle } \\
\text { fresh weight, plumule fresh weigh, radicle } \\
\text { dry weight, plumule dry weight, coleoptile } \\
\text { fresh weight, coleoptile dry weight }\end{array}$ & $10.0-21.9$ & 17 & 2 & [42] \\
\hline & $9311 \times$ japonica & CSSL & Survival rate & $5.1-93.2$ & 4 & - & [41] \\
\hline \multirow{16}{*}{ Seedling stage } & O. rufipogon $\times$ O. Sative & ILs & SDS, STT & $2-8$ & 10 & - & [64] \\
\hline & $\begin{array}{l}(\text { Nona Bokra } \times \text { Pokkali }) \times(\text { IR4630- } \\
22-2-5-1-3 \times \text { IR10167-129-3-4) }\end{array}$ & RIL & SNC, SKC, SNKR & - & 4 & - & [16] \\
\hline & IR4630×IR15324 & RIL & $\mathrm{SNC}, \mathrm{SKC}, \mathrm{SNKR}$, total $\mathrm{Na}^{+}$and $\mathrm{K}^{+}$, SDW & $6.4-19.6$ & 11 & 0 & [17] \\
\hline & Milyang $23 \times$ Gihobyeo & RIL & SST & $9.2-27.8$ & 2 & 1 & [19] \\
\hline & Milyang $23 \times$ Gihobyeo & RIL & SST & $9.1-27.8$ & 2 & 1 & [20] \\
\hline & H $359 \times$ Acc 8558 & RIL & SNC & $1.68-45.39$ & 13 & 3 & [21] \\
\hline & IR29 $\times$ Pokkali & RIL & $\begin{array}{l}\text { SNC, SKC, RKC, RNKC, SH, chlorophyll } \\
\text { content, seedling survival rate, initial and } \\
\text { final SST }\end{array}$ & $6-67$ & 27 & 16 & [22] \\
\hline & Ilpumbyeo $\times$ Moroberekan & $\mathrm{IL}$ & $\begin{array}{l}\text { The reduction rate of fresh and dry weight, } \\
\text { leaf area and SH }\end{array}$ & $10.2-13.9$ & 8 & 0 & [27] \\
\hline & $\begin{array}{l}\text { Shuhui527 } \times \text { ZDZ057, } \\
\text { Minghui } 86 \times \text { Teqing, } \\
\text { Minghui } 86 \times \text { ZDZ057, } \\
\text { Shuhui527 } \times \text { Teqing }\end{array}$ & IL & SST, SDS & $8.17-42.18$ & 43 & 12 & [28] \\
\hline & Lemont $\times$ Teqing & IL & SST, SDS, SKC, SNC & - & 36 & - & [29] \\
\hline & Pokkali $\times$ IR29 & $\mathrm{IL}$ & SST & $4.00-18.42$ & 6 & 0 & [30] \\
\hline & Ce258×IR75862, ZGX1×IR75862 & $\mathrm{IL}$ & SST, SDS, SKC, SNC & $5.13-13.75 / 3.73-8.26^{*}$ & $18 / 2 *$ & 0 & [33] \\
\hline & Tarome-Molaei $\times$ Tiqing & $\mathrm{IL}$ & SNC, SKC, SNKR, RNC, RKC, RNKR & $9.0-30.0$ & 14 & 5 & [34] \\
\hline & Xiushui $09 \times$ IR2061-520-6-9 & IL & SST, SDS, SKC, SNC, SKNR & $5.14-18.89 / 2.60-14.30 *$ & $26 / 21 *$ & 0 & [35] \\
\hline & Zaiyeqing8 $\times$ Jingxi17 & $\mathrm{DH}$ & SDS & $10.2-38.4$ & 10 & 2 & [39] \\
\hline & Nona Bokra $\times$ Koshihikari & $\mathrm{F}_{2} / \mathrm{F}_{3}$ & $\begin{array}{l}\mathrm{SDS}, \mathrm{SNC}, \mathrm{SKC}, \mathrm{RNC}, \mathrm{RKC}, \mathrm{Na}^{+} \text {and } \mathrm{K}^{+} \text {in } \\
\text { root, } \mathrm{SDW}\end{array}$ & $12.4-48.5$ & 11 & 3 & {$[44]$} \\
\hline
\end{tabular}


Table 1. Cont

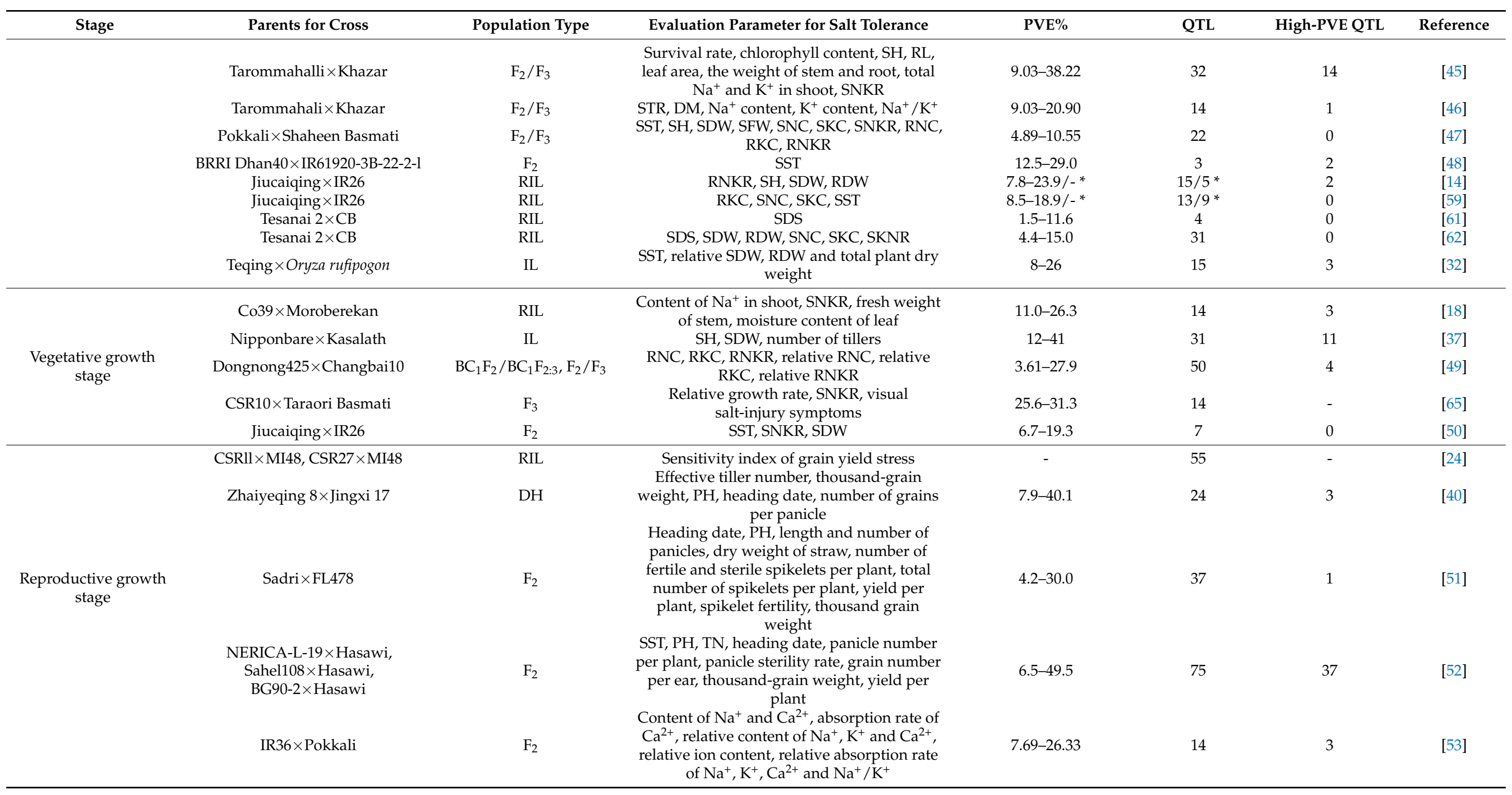


Table 1. Cont.

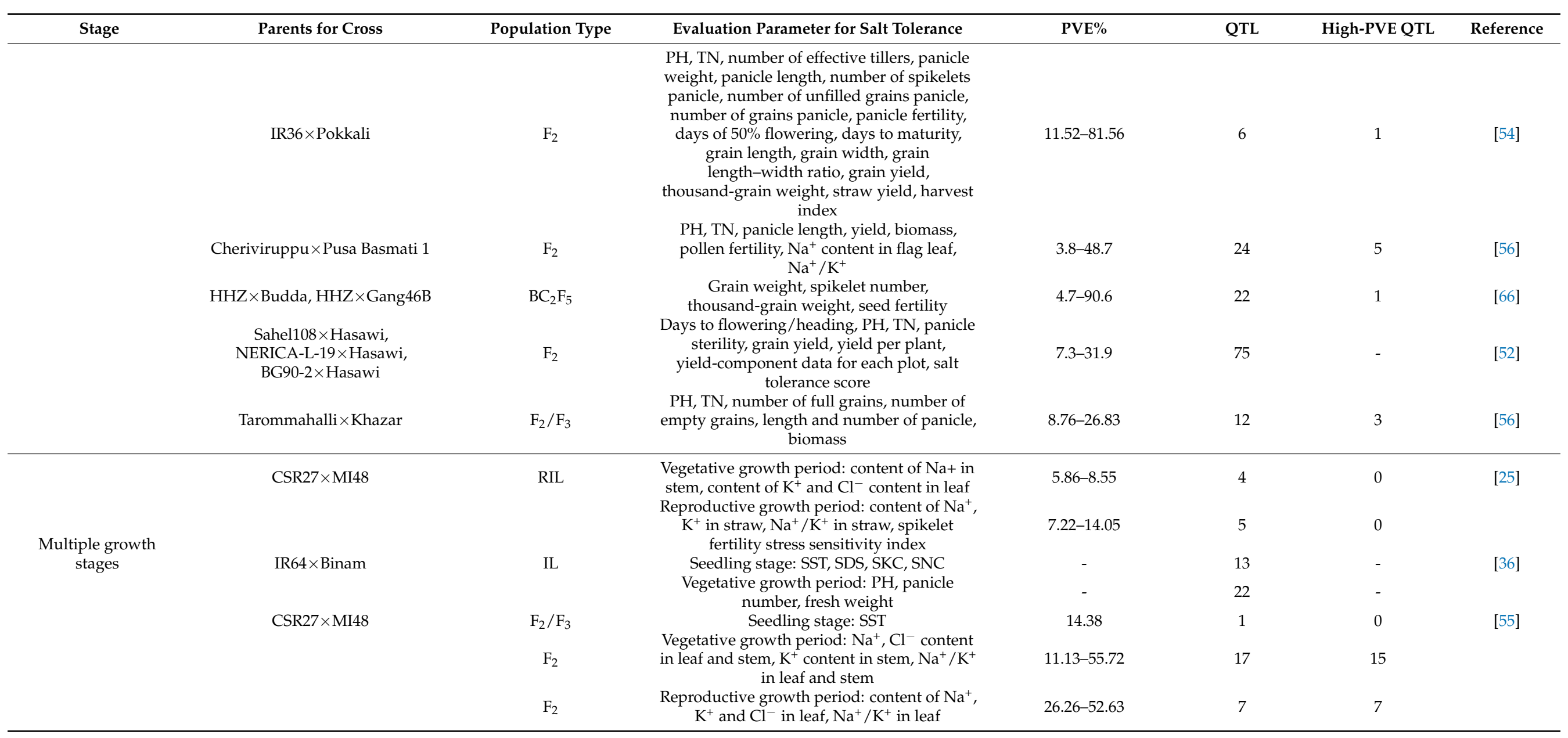


Table 1. Cont.

Stage

Parents for Cross

Peta $\times$ Pokkal
Population Type

$\mathrm{BC}_{1} \mathrm{~F}_{1}$
Evaluation Parameter for Salt Tolerance

Vegetative growth stage: SST, SFW, SDW,

$$
\mathrm{Na}^{+} \text {content }
$$

Reproductive growth stage: weight of stem

and leaf, $\mathrm{PH}$, TL, effective panicle, number,

panicle weight, main panicle length, grain

\section{PVE\%} QTL

\section{High-PVE QTL}

Reference

$$
\text { weight, seed setting rate }
$$

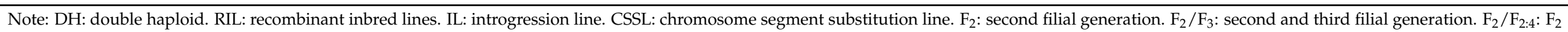

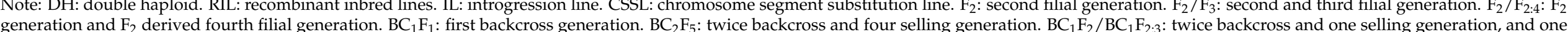

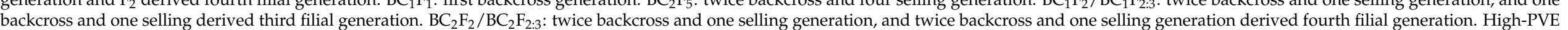

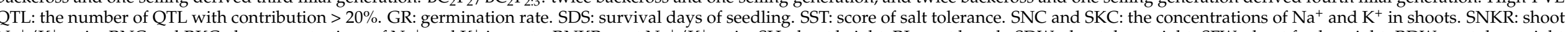

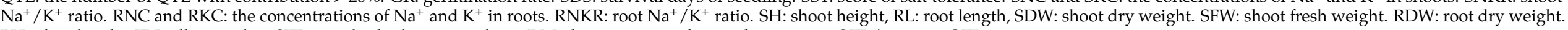

PH: plant height. TN: tiller number, STR: standard tolerance ranking, DM: dry matter weight. * indicate major QTL/epistatic QTL 
We constructed a framework genetic map using 70 QTLs with high PVE in the reports $[13,14,19-21,34,39,40,42,44,45,48,51]$ (Figure 1). Figure 1 showed that QTLs related to salt tolerance are distributed on 12 chromosomes, but less on chromosomes 11 and 12 .
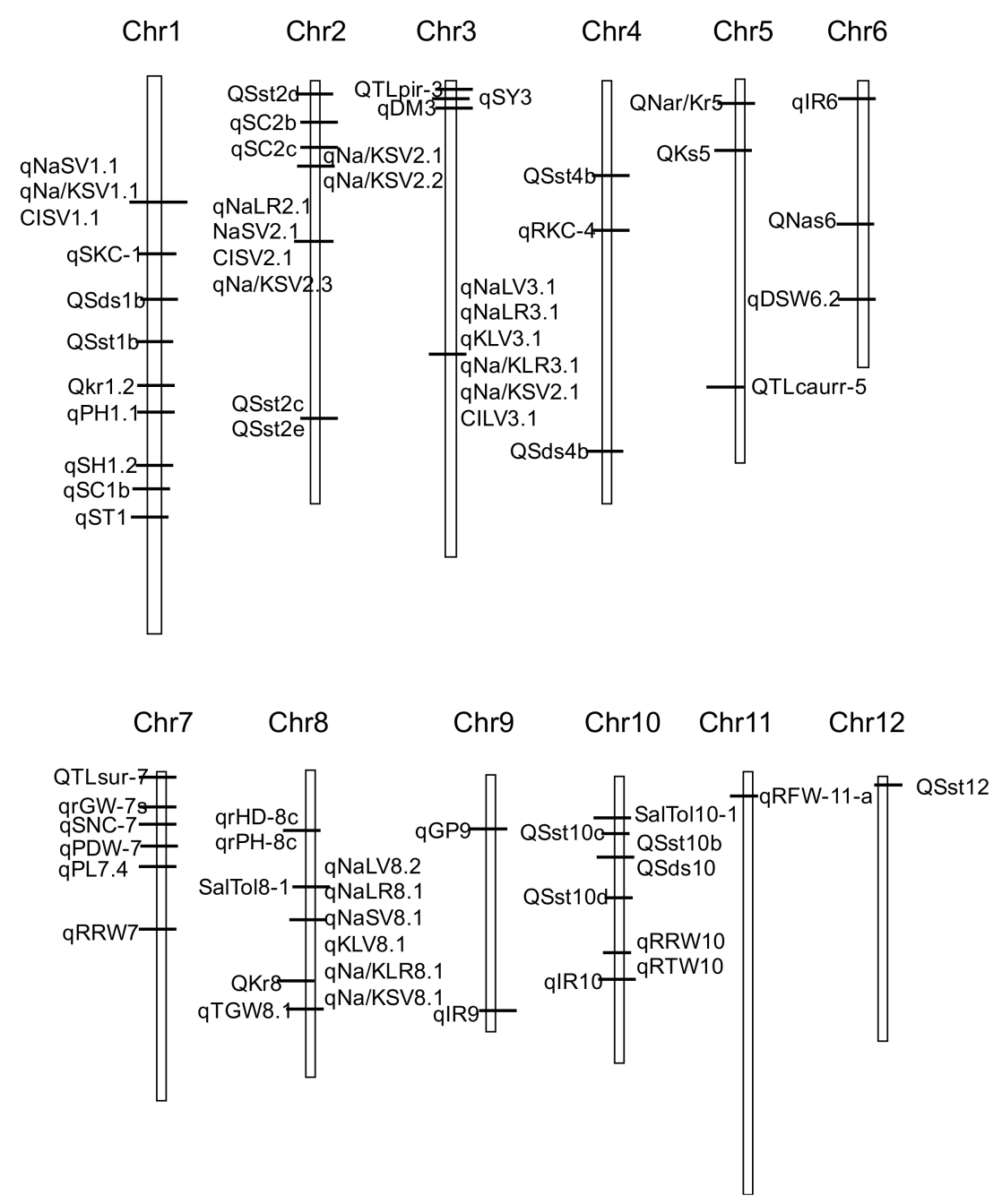

Figure 1. Genetic linkage map showing the location of QTLs for salt tolerance-related traits detected in reports.

\subsection{Fine Mapping and Map-Based Cloning of QTLs for Salt Tolerance in Rice}

Because many salt-tolerant rice QTLs have a low phenotypic contribution rate and are difficult to fine-map and clone, relevant research has progressed slowly. However, two QTLs located on the first chromosome, $q S K C-1$ and Saltol, are suitable for fine-mapping or map-based cloning.

qSKC-1 is a major QTL that controls the $\mathrm{K}^{+}$content in the shoot. It was detected in the $\mathrm{F}_{2}$ population that was constructed by the salt-tolerant variety Nona Bokra and the saltsensitive variety Koshihikari, and it explained $40.1 \%$ of the total phenotypic variation [44]. Ren et al. [67] used the map-based cloning method, followed by fine-mapping of the $\mathrm{BC}_{2} \mathrm{~F}_{2}$ population and high-precision linkage analysis of the $\mathrm{BC}_{3} \mathrm{~F}_{2}$ population, and they restricted qSKC-1 within the $7.4 \mathrm{~kb}$ chromosome interval and isolated the $q S K C-1$ gene. This gene encoded an ion transporter (OsHKT1;5) of the HKT (high-affinity $\mathrm{K}^{+}$transporter) family, which exists in the parenchyma cells of the xylem of rice roots and has the function of specifically transporting $\mathrm{Na}^{+}$. This transporter could transport $\mathrm{Na}^{+}$out of the xylem, and transport $\mathrm{Na}^{+}$from the phloem back to the root where it was excreted from the plant through the action of other $\mathrm{Na}^{+}$transporters. This process reduced the $\mathrm{Na}^{+}$content in the shoot, regulated the $\mathrm{Na}^{+} / \mathrm{K}^{+}$balance in the shoots, and improved rice salt tolerance [68]. 
Gregorio [69] used AFLP markers to analyze the salt tolerance QTL of the $\mathrm{F}_{8}$ recombinant inbred line population of the Pokkali/IR29 combination, and detected a major QTL on rice chromosome 1 that simultaneously controls the $\mathrm{Na}^{+}, \mathrm{K}^{+}$content and $\mathrm{Na}^{+} / \mathrm{K}^{+}$ratio in rice. This QTL was named Saltol. In the population, the LOD value of the Saltol site was greater than 14.5 , and the phenotypic contribution rate was $64.3-80.2 \%$. Subsequently, Bonilla et al. [70] used the same population to map Saltol to the chromosome between SSR markers RM23 and RM140, and they found that the contribution rates of Saltol sites to the $\mathrm{Na}^{+}, \mathrm{K}^{+}$content and $\mathrm{Na}^{+} / \mathrm{K}^{+}$ratio were $39.2 \%, 43.9 \%$, and $43.2 \%$, respectively. Niones and Thomson et al. [22,71] used the near-isogenic lines $\mathrm{BC}_{3} \mathrm{~F}_{4}$ and $\mathrm{BC}_{3} \mathrm{~F}_{5}$ with IR29 as the background and Pokkali as the donor to confirm the position of the Saltol locus. Since the positions of Saltol and $q S K C-1$ were nearby on the chromosome, and both were responsible for regulating the $\mathrm{Na}^{+} / \mathrm{K}^{+}$balance of rice under salt stress, Thomson et al. [22] speculated that Saltol and qSKC-1 may encode the same gene (OsHKT1;5).

Some studies conducted fine mapping and cloning on salt-tolerant and salt-sensitive mutants. Lan et al. [72] fine-mapped the seedling salt-tolerant mutant gene SST to the $17 \mathrm{~kb}$ interval on chromosome 6, and the only predicted gene in this interval is OsSPL10, which might be a candidate gene for SST. Ogawa et al. [73] and Toda et al. [74] used the salt-sensitive mutants rss1 and rss3 to clone the salt-tolerant-related genes RSS1 and RSS3, respectively. RSS1 participated in the regulation of the cell cycle and was an important factor for maintaining the viability and vigor of meristematic cells under salt stress; RSS3 regulated the expression of the jasmonic acid-responsive gene, and was involved in maintaining root cell elongation at an appropriate rate under salt stress. Deng et al. $[75,76]$ analyzed the salt-tolerant and salt-sensitive mutants $r s t 1, r s s 2$ and $r s s 4$. They detected two QTLs ( $q S N C-1$ and $q S N C-6)$ that control the $\mathrm{Na}^{+}$content of aerial parts on chromosomes 1 and 6 , which explained $14.5 \%$ and $53.3 \%$ of the phenotypic variation, respectively. The synergistic alleles were derived from $r s s 2$.

\section{Association Analysis of Rice Salt Tolerance}

Traditional QTL mapping usually uses markers to perform linkage analysis on the segregating populations derived from the parental cross $F_{1}$. This requires construction of a mapping population with a long cycle, and it has limited mapping accuracy and detectable alleles. Therefore, association analysis based on linkage disequilibrium is more widely used to analyze quantitative traits of plants $[77,78]$. Association analysis is now commonly applied to the identification of rice salt tolerance genes.

\subsection{Association Analysis of Salt Tolerance Candidate Genes}

To identify salt tolerance QTLs or candidate genes in 180 japonica rice from the European Rice Core Collection (ERCC), Ahmadi et al. [79] used 124 SNP and 52 SSR markers to associate 14 salt tolerance QTLs and 65 salt tolerance candidate genes. They identified 19 gene loci that were significantly associated with one or more salt stress traits. Negrão et al. [80] analyzed 392 rice germplasm resources by EcoTILLING technology, and they found the allele polymorphisms of five salt tolerance candidate genes, which were related to $\mathrm{Na}^{+} / \mathrm{K}^{+}$balance, signal cascade and stress protection. There were 40 new alleles in the coding sequences of these genes, and 11 SNPs related to salt tolerance in rice were identified by association analysis.

Association analysis identified QTLs, candidate genes, and alleles related to the salt tolerance of rice, and it also revealed different salt tolerance mechanisms of different genotypes of rice. However, none of the rice varieties carried favorable alleles at all salt tolerance loci $[79,80]$.

\subsection{SSR Association Analysis of Salt Tolerance}

SSR markers were used on 300 rice resources to analyze the association between salt tolerance in the seedling stage and tolerance in the whole growth period. Zheng et al. [63] identified the salt tolerance of 342 japonica rice with seedling survival days and shoot 
$\mathrm{Na}^{+} / \mathrm{K}^{+}$as evaluation indicators at the seedling stage. They used 160 pairs of SSR markers for salt tolerance association analysis. A total of twelve SSR markers were significantly associated with salt tolerance. A total of nine of the markers were close to the positions of reported salt tolerance QTLs and four markers were in the same position of known salt tolerance-related genes (OsEREBP1, OsABF2, HKT1;5 and OsAHP1). Cui et al. [81] planted 347 japonica rice on coastal tidal flats, and examined agronomic traits such as heading date, plant height, effective panicle number, grain number per panicle, spikelet fertility, and thousand-grain weight. These traits were used as evaluation parameters for salt tolerance association analysis with 148 SSR markers. The study identified 25 SSR markers linked to rice salt tolerance. These markers are located on 10 chromosomes, except for the fifth and sixth chromosomes, and explained from $4.58 \%$ to $31.65 \%$ of the phenotypic variation. Among these loci, 10 markers were consistent with, or close to, the positions of reported salt tolerance QTLs on the chromosome.

\subsection{Salt Tolerance Genome-Wide Association Analysis}

Genome-wide association analysis (GWAS) has recently played an important role in discovering genes that regulate plant salt tolerance [82]. Through phenotypic variation analysis, GWAS can analyze the interactions between traits that previously seemed independent, and this can help explain the interactions among potential genes [83-85].

Kumar et al. [86] identified rice salt tolerance gene loci with 220 rice materials, and they performed an association analysis on 12 agronomic traits related to salt tolerance during the reproductive growth stage and the accumulation of $\mathrm{Na}^{+}$and $\mathrm{K}^{+}$in leaves. They identified 20 SNPs significantly related to leaf $\mathrm{Na}^{+} / \mathrm{K}^{+}$, and 44 SNPs related to other salt tolerance traits. These gene loci explained $5-18 \%$ of the phenotypic variation. Zhang et al. [87] used a multiparent advanced generation intercross population, DC1, and identified salt tolerance QTLs by GWAS. There were 7 QTLs delineated from 186 associations that were detected on chromosomes 1, 2, 5 and 9, which explained 7.42-9.38\% of the total phenotypic variation. Liu et al. [88] found five known genes (OsSUT1, OsCTR3, OsMYB6, OsHKT1;4, and OsGAMYB) and two novel genes (LOC_Os02g49700 and LOC_Os03g28300) that were associated with grain yield under salinity stress. Batayeva et al. [89] performed GWAS on 9 seedling salt tolerance traits of 191 japonica rice, and they detected 26 significant loci. Neang et al. [90] used 296 accessions of rice to identify salt-related traits and used 36,901 SNPs to conduct GWAS. They found 13 candidate genes. Yu et al. [91] used 295 accessions and identified 93 candidate genes with high association peaks of salt stress. Cui et al. [92] reported six multi-locus GWAS methods (mrMLM, FASTmrMLM, FASTmrEMMA, pLARmEB, pKWmEB, and ISIS EM-BLASSO), and identified 162,529 SNPs at the seed germination stage for salt tolerance traits with 478 rice accessions. Lekklar et al. [93] conducted a GWAS of salt tolerance using Thai rice accessions, and they found 164 genes colocalized with reported salt quantitative trait loci. These accounted for $73 \%$ of the identified loci. Yu et al. [94] performed a GWAS of salt-tolerance-related phenotypes in rice during the germination stage with 295 accessions. They found OsMADS31, one of the MADS-box family transcription factors, had down-regulated expression and was predicted to participate in salt stress at the germination stage. Rohila et al. [95] conducted a GWAS of early vigor traits under salt stress with the natural genetic variation in the United States Department of Agriculture rice mini-core collection. They identified 14 salt-tolerant accessions, 6 new loci, and 16 candidate genes that could contribute to salt tolerance breeding. Warraich et al. [96] evaluated 180 rice accessions for salinity tolerance at the reproductive stage by GWAS and 19 associations were identified for $\mathrm{Na}^{+}, \mathrm{K}^{+}$and $\mathrm{Na}^{+} / \mathrm{K}^{+}$uptake in leaves and stems. Based on 6,361,920 single nucleotide polymorphisms in 478 rice accessions, Shi et al. [97] identified 22 salt tolerance-associated SNPs based on salt tolerance-related traits. There were seven loci on chromosomes 1, 5, 6, 11, and 12 that were close to six previously identified quantitative gene loci/genes related to salinity tolerance. These studies showed that there were some genes expected to be involved in salt resistance in rice, including a nitrate transporter gene OsNRT2.1 [97], a MADS-box family transcription factor gene OsMADS31 [94], 
a sucrose transport protein gene OsSUT1, a transcript factor gene OsGAMYB, and some function genes OsCTR3, OsMYB6 and OsHKT1;4 [88], etc. With the development of variety resequencing, salt tolerance GWAS has rapidly developed [98-105]. GWAS has exploited the natural variation in root architecture remodeling under salt tolerance to uncover the genetic controls underlying plant responses $[83,106]$. The studies provide insight into the genetic structure of salt tolerance and are important resources for breeding programs.

In Table 2, we summarize 25 association analyses of salt tolerance with more than 600 genetic sites related to salt tolerance in rice

Table 2. Association analysis of salt tolerance in rice.

\begin{tabular}{|c|c|c|c|c|c|}
\hline Stage & Population Size & Maker Type & QTL & Traits & Reference \\
\hline \multirow{3}{*}{ Generation stage } & 478 & SNP (6.36M) & 11 & \multirow{3}{*}{$\begin{array}{c}\text { GR, germination index, vigor index, } \\
\text { germination time, and imbibition rate } \\
\text { GR, germination energy, germination index, } \\
\text { SH, RL } \\
\text { RL under control condition, alkaline stress } \\
\text { and relative RL }\end{array}$} & [97] \\
\hline & 295 & SNP (1.65M) & 12 & & [94] \\
\hline & 184 & SNP (788K) & 8 & & [101] \\
\hline \multirow{14}{*}{ Seedling stage } & 32 & SSR (64) & 28 & \multirow{14}{*}{$\begin{array}{c}\text { Salt tolerance level } \\
\text { SST, SNC, SKC, RNC and RKC } \\
\text { Relative growth rate, transpiration use } \\
\text { efficiency and transpiration rates } \\
\text { Leaf width, SH, RL, total dry weight } \\
\text { Tiller number, SH, RL, SDW, RDW, } \\
\text { RDW /SDW, leaf area, SNKR } \\
\text { SNC, SKC } \\
\text { Shoot } \mathrm{Na}^{+} \text {and } \mathrm{K}^{+} \text {content, standard } \\
\text { evaluation score, percentage of damage, } \\
\text { SDW } \\
\text { SDS, SSI } \\
\text { SSI, SDW, RDW, SDS } \\
\text { Salinization damage grade, SNC, SKC, } \\
\text { SNKR } \\
\text { SES, SDS, SH and RL under salt treatment, } \\
\text { relative SH and RL, SDW and RDW after } \\
\text { salt treatment, relative SDW and RDW, } \\
\text { relative biomass. } \\
\text { SH, SFW and SDW under control, salt stress } \\
\text { conditions, relative SH, SFW and SDW } \\
\text { SST, SNC, SKC, SNKR } \\
\text { SH, RL, SFW, SDW, RFW, RDW, salt } \\
\text { tolerance level }\end{array}$} & [107] \\
\hline & 342 & SSR (160) & 12 & & [15] \\
\hline & 533 & SNP (700K) & 20 & & [108] \\
\hline & 295 & SNP (1.65M) & 25 & & [91] \\
\hline & 235 & SNP (30K) & 27 & & [79] \\
\hline & 306 & SNP (200K) & 58 & & {$[103]$} \\
\hline & 203 & SNP (68K) & 26 & & [89] \\
\hline & 708 & SNP (3.45M) & 41 & & [88] \\
\hline & 162 & $\mathrm{SNP}(3.2 \mathrm{M})$ & 9 & & [95] \\
\hline & 176 & SSR (154) & 13 & & [109] \\
\hline & 221 & SNP (55K) & 7 & & [87] \\
\hline & 181 & SNP (32K) & 54 & & [98] \\
\hline & 295 & SNP (788K) & 8 & & [100] \\
\hline & 664 & SNP (3M) & 21 & & [105] \\
\hline \multirow{4}{*}{$\begin{array}{l}\text { Vegetative } \\
\text { growth stage }\end{array}$} & 104 & SNP (112K) & 200 & $\begin{array}{l}\text { Photosynthetic parameters and cell } \\
\text { membrane stability }\end{array}$ & [93] \\
\hline & 296 & SNP (44K) & 11 & $\begin{array}{c}\mathrm{Na}^{+} \text {and } \mathrm{Cl}^{-} \text {of leaf blades, } \mathrm{Na}^{+} \text {and } \mathrm{Cl}^{-} \\
\text {sheath:blade ratios, } \mathrm{SES}\end{array}$ & [90] \\
\hline & 179 & SNP (21K) & 26 & $\begin{array}{l}\text { SES, chlorophyll content, water content, } \mathrm{Na}^{+} \\
\text {and } \mathrm{K}^{+} \text {contents, SNKR }\end{array}$ & [99] \\
\hline & 96 & SNP (50K) & 23 & $\begin{array}{l}\text { SH, RL, SFW, SDW, RFW, RDW, RNC, SNC, } \\
\text { RKC, SKC, RNK, SNKR, RNKR }\end{array}$ & {$[104]$} \\
\hline \multirow{2}{*}{$\begin{array}{l}\text { Reproductive } \\
\text { growth stage }\end{array}$} & 220 & $\mathrm{SNP}(6 \mathrm{~K})$ & 64 & $\begin{array}{l}\text { SNKR, PH, TN, spikelet fertility, unfilled or } \\
\text { filled grains, yield }\end{array}$ & [86] \\
\hline & 347 & SSR (148) & 25 & Salinity tolerance index & [81] \\
\hline \multirow{2}{*}{$\begin{array}{l}\text { Multiple growth } \\
\text { stages }\end{array}$} & 180 & SSR (150) & 28 & $\begin{array}{c}\mathrm{Na}^{+}, \mathrm{K}^{+}, \mathrm{Ca}^{2+}, \mathrm{Mg}^{2+} \text { content in stem and } \\
\text { leaves, grain yield and SSI }\end{array}$ & [96] \\
\hline & 208 & SNP (395K) & 20 & Generation stage: GR.Seedling stage: $\mathrm{SH}, \mathrm{RL}$ & [102] \\
\hline
\end{tabular}

Note: GR: germination rate. SDS: survival days of seedling. SSI: salt stress injury score. SST: score of salt tolerance. SNC and SKC: the concentrations of $\mathrm{Na}^{+}$and $\mathrm{K}^{+}$in shoots. SNKR: shoot $\mathrm{Na}^{+} / \mathrm{K}^{+}$ratio. RNC and RKC: the concentrations of $\mathrm{Na}^{+}$and $\mathrm{K}^{+}$in roots. RNKR: root $\mathrm{Na}^{+} / \mathrm{K}^{+}$ratio. SES: standard evaluation system score. SH: shoot height, RL: root length, SDW: shoot dry weight. SFW: shoot fresh weight. RDW: root dry weight. RFW: root fresh weight. PH: plant height. TN: tiller number.

\section{Issues and Prospects}

Most studies of rice salt tolerance gene mapping and cloning evaluated the salt tolerance of a specific growth and development stage such as the seedling stage. Few 
studies have evaluated salt tolerance in multiple growth stages. Due to the differences in the salt tolerance of rice at different growth and development stages, it is necessary to conduct QTL analysis or association mapping for salt tolerance in the different growth stages of rice, especially the seedling stage and reproductive growth stage. This will enable identification of genes that simultaneously control salt tolerance in multiple growth stages. This research could begin by screening salt-tolerant rice germplasm resources during the whole growth period, and then identifying materials that complete their life cycle under salt stress with less impact on yield traits. This approach could be useful for salt-tolerant gene mapping, cloning, and breeding.

Hundreds of QTLs related to salt tolerance have been identified but the progress of follow-up work on fine-mapping and map-based cloning of genes has been slow. One reason is the lack of salt-tolerant rice varieties in the parental combinations. A small difference in salt tolerance between the two parents may only result in a small contribution to the phenotype of the identified QTLs and disturb the fine-mapping by the genetic background. However, most of salt-tolerant QTL mapping studies involved a single time period or a single-year phenotypic identification, and there was a lack of QTL stability. Some salt-tolerant QTLs with a high phenotypic contribution rate (above $20 \%$ ) could be difficult to fine-map and clone due to poor genetic stability. Therefore, it is necessary to select strong salt-tolerant rice varieties for salt-tolerant QTL mapping, and also to test the stability of salt-tolerant QTLs multiple times or by multi-year multi-point experiments for gene cloning and breeding.

For mining salt-tolerant genes for salt-tolerant germplasm resources, traditional QTL analysis methods could be combined with mutant construction, screening, and association analysis. Association analysis, especially GWAS, is now commonly used for the analysis of complex traits of plants, and it aids understanding of the genetic basis and differentiation of salt tolerance in rice. Using QTL mapping and GWAS, the genetic basis of many complex quantitative traits has been analyzed and many QTL segments or loci have been located. With the development of genome sequencing technology and bioinformatics, using the reference genome sequence information of the corresponding species could help determine the candidate genes related to the target trait and narrow the range of candidate genes [110,111]. Moreover, GWAS is useful for marker-assisted selection (MAS) of rice varieties suitable for cultivation in salinized fields.

With the development of molecular marker technology, MAS technology is now widely used in crop breeding, thus providing a new way to accelerate the genetic improvement of rice salt tolerance. MAS could select target traits in early generations, accelerate the breeding process, and aggregate multiple beneficial genes at the same time to improve breeding efficiency [112]. A QTL for salt tolerance in rice that is frequently used in MAS breeding is Saltol, which is located on chromosome 1 [113]. Saltol QTL is a major QTL associated with the $\mathrm{Na}^{+} / \mathrm{K}^{+}$ratio and salinity tolerance at the seedling stage in rice. Several genes have been reported in the Saltol QTL (LEA, CaMBP, V-ATPase, GST, OSAP1 zing finger protein and transcription factor $H B P 1 b$ ) that were salinity sensitive and regulated between the genotypes [114-116]. Most studies were performed using marker-assisted backcrossing (MABC) technology in India, the Philippines, Bangladesh, Thailand, Vietnam and Senegal [117-119]. Some Saltol introgression lines cultivated by MAS, such as BR11-SalTol and BRRI dhan28-SalTol, have been tested in salt damaged coastal areas in the Philippines, Bangladesh, India, and Vietnam [113,120]. Bimpong et al. [113] found that compared with traditional breeding, MAS breeding can shorten the germplasm improvement time by four to seven years.

Author Contributions: Conceptualization, L.M. and J.C.; writing-original draft preparation, X.F., H.J. and J.C.; data curation, X.F., H.J. and J.C.; supervision, L.M. and J.C. All authors have read and agreed to the published version of the manuscript.

Funding: This research was financially supported by the National Natural Science Foundation of China (31902103), Doctoral Scientific Research Foundation of Anshan Normal University (21b04), 
Postgraduate Research and Practice Innovation Program of Jiangsu Province (KYCX19_0546), and Shenzhen Science and Technology Projects (No. JCYJ20210324124409027 to J.C.).

Institutional Review Board Statement: Not applicable.

Informed Consent Statement: Not applicable.

Data Availability Statement: All of the data generated or analyzed during this study are included in this published article.

Conflicts of Interest: The authors declare no conflict of interest.

\section{References}

1. Ismail, A.M.; Horie, T. Genomics, Physiology, and Molecular Breeding Approaches for Improving Salt Tolerance. Annu. Rev. Plant Biol. 2017, 68, 405-434. [CrossRef] [PubMed]

2. Chinnusamy, V.; Jagendorf, A.; Zhu, J.K. Understanding and Improving Salt Tolerance in Plants. Crop Sci. 2005, 45, 437-448. [CrossRef]

3. Munns, R.; Tester, M. Mechanisms of salinity tolerance. Annu. Rev. Plant Biol. 2008, 59, 651-681. [CrossRef]

4. Zeng, L.; Shannon, M.C.; Grieve, C.M. Evaluation of salt tolerance in rice genotypes by multiple agronomic parameters. Euphytica 2002, 127, 235-245. [CrossRef]

5. Ponce, K.S.; Meng, L.; Guo, L.; Leng, Y.; Ye, G. Advances in Sensing, Response and Regulation Mechanism of Salt Tolerance in Rice. Int. J. Mol. Sci. 2021, 22, 2254. [CrossRef] [PubMed]

6. Al-Tamimi, N.; Oakey, H.; Tester, M.; Negrão, S. Assessing Rice Salinity Tolerance: From Phenomics to Association Mapping. In Rice Genome Engineering and Gene Editing: Methods and Protocols; Bandyopadhyay, A., Thilmony, R., Eds.; Springer: New York, NY, USA, 2021; pp. 339-375.

7. Quan, R.; Wang, J.; Hui, J.; Bai, H.; Lyu, X.; Zhu, Y.; Zhang, H.; Zhang, Z.; Li, S.; Huang, R. Improvement of Salt Tolerance Using Wild Rice Genes. Front. Plant Sci. 2017, 8, 2269. [CrossRef] [PubMed]

8. Deinlein, U.; Stephan, A.B.; Horie, T.; Luo, W.; Xu, G.; Schroeder, J.I. Plant salt-tolerance mechanisms. Trends Plant Sci. 2014, 19, 371-379. [CrossRef] [PubMed]

9. Morton, M.J.L.; Awlia, M.; Al-Tamimi, N.; Saade, S.; Pailles, Y.; Negrão, S.; Tester, M. Salt stress under the scalpel-dissecting the genetics of salt tolerance. Plant J. 2019, 97, 148-163. [CrossRef] [PubMed]

10. Zelm, E.v.; Zhang, Y.; Testerink, C. Salt Tolerance Mechanisms of Plants. Annu. Rev. Plant Biol. 2020, 71, 403-433. [CrossRef]

11. Shan, T.; Pang, S.; Wang, X.; Li, J.; Li, Q.; Su, L.; Li, X. A method to establish an "immortalized F-2" sporophyte population in the economic brown alga Undaria pinnatifida (Laminariales: Alariaceae). J. Phycol. 2020, 56, 1748-1753. [CrossRef] [PubMed]

12. Mazumder, A.; Rohilla, M.; Bisht, D.S.; Krishnamurthy, S.L.; Barman, M.; Sarma, R.N.; Sharma, T.R.; Mondal, T.K. Identification and mapping of quantitative trait loci (QTL) and epistatic QTL for salinity tolerance at seedling stage in traditional aromatic short grain rice landrace Kolajoha (Oryza sativa L.) of Assam, India. Euphytica 2020, 216, 1211-1226. [CrossRef]

13. Wang, Z.; Wang, J.; Bao, Y.; Wu, Y.; Zhang, H. Quantitative trait loci controlling rice seed germination under salt stress. Euphytica 2010, 178, 297-307. [CrossRef]

14. Wang, Z.; Cheng, J.; Chen, Z.; Huang, J.; Bao, Y.; Wang, J.; Zhang, H. Identification of QTLs with main, epistatic and QTL x environment interaction effects for salt tolerance in rice seedlings under different salinity conditions. Theor. Appl. Genet. 2012, 125, 807-815. [CrossRef] [PubMed]

15. Zheng, H.; Zhao, H.; Liu, H.; Wang, J.; Zou, D. QTL analysis of Na+ and K+ concentrations in shoots and roots under NaCl stress based on linkage and association analysis in japonica rice. Euphytica 2014, 201, 109-121. [CrossRef]

16. Flowers, T.J.; Koyama, M.L.; Flowers, S.A.; Sudhakar, C.; Singh, K.P.; Yeo, A.R. QTL: Their place in engineering tolerance of rice to salinity. J. Exp. Bot. 2000, 51, 99-106. [CrossRef]

17. Koyama, M.L.; Levesley, A.; Koebner, R.; Flowers, T.; Yeo, A.R. Quantitative Trait Loci for Component Physiological Traits Determining Salt Tolerance in Rice. Plant Physiol. 2001, 125, 406-422. [CrossRef]

18. Haq, U.T.; Gorham, J.; Akhtar, J.; Akhtar, N.; Steele, K.A. Dynamic quantitative trait loci for salt stress components on chromosome 1 of rice. Funct. Plant Biol. 2010, 37, 634-645. [CrossRef]

19. Lee, S.; Ahn, J.; Cha, Y.; Yun, D.; Lee, M.; Ko, J.; Lee, K.; Eun, M. Mapping of quantitative trait loci for salt tolerance at the seedling stage in rice. Mol. Cells 2006, 21, 192-196. [PubMed]

20. Lee, S.Y.; Ahn, J.H.; Cha, Y.S.; Yun, D.W.; Lee, M.C.; Ko, J.C.; Lee, K.S.; Eun, M.Y. Mapping QTLs related to salinity tolerance of rice at the young seedling stage. Plant Breed. 2007, 126, 43-46. [CrossRef]

21. Wang, B.; Lan, T.; Wu, W. Mapping of QTLs for Na+ content in rice seedlings under salt stress. Chin. J. Rice Sci. 2007, 21, 585-590.

22. Thomson, M.J.; de Ocampo, M.; Egdane, J.; Rahman, M.A.; Sajise, A.G.; Adorada, D.L.; Tumimbang-Raiz, E.; Blumwald, E.; Seraj, Z.I.; Singh, R.K.; et al. Characterizing the Saltol Quantitative Trait Locus for Salinity Tolerance in Rice. Rice 2010, 3, 148-160. [CrossRef]

23. Liang, J.; Qu, Y.; Yang, C.; Ma, X.; Cao, G.; Zhao, Z.; Zhang, S.; Zhang, T.; Han, L. Identification of QTLs associated with salt or alkaline tolerance at the seedling stage in rice under salt or alkaline stress. Euphytica 2014, 201, 441-452. [CrossRef] 
24. Tiwari, S.; Sl, K.; Kumar, V.; Singh, B.; Rao, A.R.; Mithra SV, A.; Rai, V.; Singh, A.K.; Singh, N.K. Mapping QTLs for Salt Tolerance in Rice (Oryza sativa L.) by Bulked Segregant Analysis of Recombinant Inbred Lines Using 50K SNP Chip. PLoS ONE 2016, 11, e0153610. [CrossRef]

25. Pandit, A.; Rai, V.; Bal, S.; Sinha, S.; Kumar, V.; Chauhan, M.; Gautam, R.K.; Singh, R.; Sharma, P.C.; Singh, A.K.; et al. Combining QTL mapping and transcriptome profiling of bulked RILs for identification of functional polymorphism for salt tolerance genes in rice (Oryza sativa L.). Mol. Genet. Genom. 2010, 284, 121-136. [CrossRef] [PubMed]

26. Sun, Y.; Zang, J.; Wang, Y.; Zhu, L.; Mohammadhosein, F.; Xu, J.; Li, Z. Mining Favorable Salt-tolerant QTL from Rice Germplasm Using a Backcrossing Introgression Line Population. Acta Agron. Sin. 2007, 33, 1611-1617.

27. Kim, D.M.; Ju, H.G.; Kwon, T.R.; Oh, C.S.; Ahn, S.N. Mapping QTLs for salt tolerance in an introgression line population between Japonica cultivars in rice. J. Crop Sci. Biotech. 2009, 12, 121-128. [CrossRef]

28. Qian, Y.; Wang, H.; Chen, M.; Zhang, L.; Chen, B.; Cui, J.; Liu, H.; Zhu, L.; Shi, Y.; Gao, Y.; et al. Detection of Salt-tolerant QTL Using BC2F3 Yield Selected Introgression Lines of Rice (Oryza sativa L.). Mol. Plant Breed. 2009, 7, $224-232$.

29. Yang, J.; Sun, Y.; Cheng, L.R.; Zhou, Z.; Wang, Y.; Zhu, L.H.; Cang, J.; Xu, J.L.; Li, Z.K. Genetic Background Effect on QTL Mapping for Salt Tolerance Revealed by a Set of Reciprocal Introgression Line Populations in Rice. Acta Agron. Sin. 2009, 35, 974-982. [CrossRef]

30. Alam, R.; Rahman, M.S.; Seraj, Z.I.; Thomson, M.J.; Ismail, A.M.; Tumimbang-Raiz, E.; Gregorio, G.B. Investigation of seedlingstage salinity tolerance QTLs using backcross lines derived from Oryza sativa L. Pokkali. Plant Breed. 2011, 130, 430-437. [CrossRef]

31. Li, Y.F.; Zheng, Y.; Vemireddy, L.R.; Panda, S.K.; Jose, S.; Ranjan, A.; Panda, P.; Govindan, G.; Cui, J.; Wei, K.; et al. Comparative transcriptome and translatome analysis in contrasting rice genotypes reveals differential mRNA translation in salt-tolerant Pokkali under salt stress. BMC Genom. 2018, 19, 935. [CrossRef] [PubMed]

32. Tian, L.; Tan, L.; Liu, F.; Cai, H.; Sun, C. Identification of quantitative trait loci associated with salt tolerance at seedling stage from Oryza rufipogon. J. Genet. Genom. 2011, 38, 593-601. [CrossRef]

33. Qiu, X.; Yuan, Z.; Liu, H.; Xiang, X.; Yang, L.; He, W.; Du, B.; Ye, G.; Xu, J.; Xing, D.; et al. Identification of salt tolerance-improving quantitative trait loci alleles from a salt-susceptible rice breeding line by introgression breeding. Plant Breed. 2015, 134, 653-660 [CrossRef]

34. Ahmadi, J.; Fotokian, M.H. Identification and mapping of quantitative trait loci associated with salinity tolerance in rice (Oryza Sativa) using SSR markers. Iran. J. Biotechnol. 2011, 9, 21-30.

35. Cheng, L.; Wang, Y.; Meng, L.; Hu, X.; Cui, Y.; Sun, Y.; Zhu, L.; Ali, J.; Xu, J.; Li, Z. Identification of salt-tolerant QTLs with strong genetic background effect using two sets of reciprocal introgression lines in rice. Genome 2012, 55, 45-55. [CrossRef] [PubMed]

36. Zang, J.; Sun, Y.; Wang, Y.; Yang, J.; Li, F.; Zhou, Y.; Zhu, L.; Jessica, R.; Mohammadhosein, F.; Xu, J.; et al. Dissection of genetic overlap of salt tolerance QTLs at the seedling and tillering stages using backcross introgression lines in rice. Sci. China C Life Sci. 2008, 51, 583-591. [CrossRef] [PubMed]

37. Takehisa, H.; Shimodate, T.; Fukuta, Y.; Ueda, T.; Yano, M.; Yamaya, T.; Kameya, T.; Sato, T. Identification of quantitative trait loci for plant growth of rice in paddy field flooded with salt water. Field Crop. Res. 2004, 89, 85-95. [CrossRef]

38. Prasad, S.; Bagali, P.; Hittalmani, S.; Shashidhar, H. Molecular mapping of quantitative trait loci associated with seedling tolerance to salt stress in rice (Oryza sativa L). Curr. Sci. 2000, 78, 162-164.

39. Gong, J.; He, P.; Qian, Q.; Shen, L.; Zhu, L.; Chen, S. Identification of salt-tolerance QTL in rice (Oryza sativa L.). Chin. Sci. Bull. 1999, 41, 68-71. [CrossRef]

40. Gong, J.; Zheng, X.; Du, B.; Qian, Q.; Chen, S.; Zhu, L.; He, P. Comparative study of QTLs for agronomic traits of rice (Oryza sativa L.) between salt stress and nonstress environment. Sci. China C Life Sci. 2001, 44, 73-82. [CrossRef] [PubMed]

41. Zhao, C.; Zhang, S.; Zhao, Q.; Zhou, L.; Zhao, L.; Yao, S.; Zhang, Y.; Wang, C. Mapping of QTLs for bud-stage salinity tolerance based on chromosome segment substitution line in rice. Acta Agric. Boreali-Sin. 2017, 32, 106-111.

42. Mardani, Z.; Rabiei, B.; Sabouri, H.; Sabouri, A.; Virk, P. Identification of molecular markers linked to salt-tolerant genes at germination stage of rice. Plant Breed. 2014, 133, 196-202. [CrossRef]

43. Ghomi, K.; Rabiei, B.; Sabouri, H.; Sabouri, A. Mapping QTLs for traits related to salinity tolerance at seedling stage of rice (Oryza sativa L.): An agrigenomics study of an Iranian rice population. OMICS 2013, 17, 242-251. [CrossRef]

44. Lin, H.X.; Zhu, M.Z.; Yano, M.; Gao, J.P.; Liang, Z.W.; Su, W.A.; Hu, X.H.; Ren, Z.H.; Chao, D.Y. QTLs for Na+ and K+ uptake of the shoots and roots controlling rice salt tolerance. Theor. Appl. Genet. 2004, 108, 253-260. [CrossRef] [PubMed]

45. Sabouri, H.; Sabouri, A. New evidence of QTLs attributed to salinity tolerance in rice. Afr. J. Biotechnol. $2008,7,4376-4383$.

46. Sabouri, H.; Rezai, A.; Moumeni, A.; Kavousi, A.; Katouzi, M.; Sabouri, A. QTLs mapping of physiological traits related to salt tolerance in young rice seedlings. Biol. Plant. 2009, 53, 657-662. [CrossRef]

47. Javed, M.A.; Huyop, F.Z.; Wagiran, A.; Salleh, F.M. Identification of QTLs for Morph-Physiological Traits Related to Salinity Tolerance at Seedling Stage in Indica Rice. Procedia Environ. Sci. 2011, 8, 389-395. [CrossRef]

48. Islam, M.; Salam, M.; Hassan, L.; Collard, B.Y.; Singh, R.; Gregorio, G. QTL mapping for salinity tolerance at seedling stage in rice. Emir. J. Food Agric. 2011, 23, 137. [CrossRef]

49. Sun, J.; Zou, D.T.; Luan, F.S.; Zhao, H.W.; Wang, J.G.; Liu, H.L.; Xie, D.W.; Su, D.Q.; Ma, J.; Liu, Z.L. Dynamic QTL analysis of the $\mathrm{Na}+$ content, $\mathrm{K}+$ content, and $\mathrm{Na}+/ \mathrm{K}+$ ratio in rice roots during the field growth under salt stress. Biol. Plant. 2014, 58, 689-696. [CrossRef] 
50. Yao, M.; Wang, J.; Chen, H.; Zhai, H.; Zhang, H. Inheritance and QTL mapping of salt tolerance in rice. Rice Sci. 2005, 12, 25-32.

51. Mohammadi, R.; Mendioro, M.; Diaz, G.; Gregorio, G.; Singh, R. Mapping quantitative trait loci associated with yield and yield components under reproductive stage salinity stress in rice (Oryza sativa L.). J. Genet. 2013, 93, 433-443. [CrossRef] [PubMed]

52. Bimpong, I.K.; Manneh, B.; Diop, B.; Ghislain, K.; Sow, A.; Amoah, N.K.A.; Gregorio, G.; Singh, R.K.; Ortiz, R.; Wopereis, M. New quantitative trait loci for enhancing adaptation to salinity in rice from Hasawi, a Saudi landrace into three African cultivars at the reproductive stage. Euphytica 2014, 200, 45-60. [CrossRef]

53. Khan, M.S.K.; Saeed, M.; Iqbal, J. Identification of quantitative trait loci for $\mathrm{Na}+, \mathrm{K}+$ and $\mathrm{Ca}++$ accumulation traits in rice grown under saline conditions using F2 mapping population. Braz. J. Bot. 2015, 38, 555-565. [CrossRef]

54. Khan, M.S.K.; Saeed, M.; Iqbal, J. Quantitative trait locus mapping for salt tolerance at maturity stage in indica rice using replicated F2 population. Braz. J. Bot. 2016, 39, 641-650. [CrossRef]

55. Ammar, M.; Pandit, A.; Singh, R.; Sameena, S.; Chauhan, M.; Singh, A.; Sharma, P.; Gaikwad, K.; Sharma, T.; Mohapatra, T.; et al. Mapping of QTLs controlling $\mathrm{Na}+, \mathrm{K}+$ and $\mathrm{Cl}-$ ion concentrations in salt tolerant indica rice variety. J. Plant Biochem. Biot. 2009, 18, 139-150. [CrossRef]

56. Hossain, H.; Rahman, M.A.; Alam, M.S.; Singh, R.K. Mapping of Quantitative Trait Loci Associated with Reproductive-Stage Salt Tolerance in Rice. J. Agron. Crop Sci. 2015, 201, 17-31. [CrossRef]

57. Gu, X.; Mei, M.; Yan, X.; Zheng, S.; Lu, Y. Preliminary detection of quantitative trait loci for salt tolerance in rice. Chin. J. Rice Sci. 2000, 14, 65-70. [CrossRef]

58. Negrão, S.; Courtois, B.; Ahmadi, N.; Abreu, I.; Saibo, N.; Oliveira, M.M. Recent Updates on Salinity Stress in Rice: From Physiological to Molecular Responses. Crit. Rev. Plant Sci. 2011, 30, 329-377. [CrossRef]

59. Wang, Z.; Chen, Z.; Cheng, J.; Lai, Y.; Wang, J.; Bao, Y.; Huang, J.; Zhang, H. QTL analysis of Na+ and K+ concentrations in roots and shoots under different levels of $\mathrm{NaCl}$ stress in rice (Oryza sativa L.). PLoS ONE 2012, 7, e51202. [CrossRef] [PubMed]

60. IRRI. Standard Evaluation System for Rice, 4th ed.; International Rice Research Institute: Manila, Philippines, 1996 ; Volume 52.

61. Lin, H.; Yanagihara, S.; Zhuang, J.; Senboku, T.; Yashima, S. Identification of QTL for salt tolerance in rice via molecular markers. Chin. J. Rice Sci. 1998, 12, 72-78. [CrossRef]

62. Masood, M.; Seiji, Y.; Shinwari, Z.; Anwar, R. Mapping quantitative trait loci (QTLs) for salt tolerance in rice (Oryza sativa) using RFLPs. Pak. J. Bot. 2004, 36, 825-834.

63. Zheng, H.; Wang, J.; Zhao, H.; Liu, H.; Sun, J.; Guo, L.; Zou, D. Genetic structure, linkage disequilibrium and association mapping of salt tolerance in japonica rice germplasm at the seedling stage. Mol. Breed. 2015, 35, 152. [CrossRef]

64. Wang, S.; Cao, M.; Ma, X.; Chen, W.; Zhao, J.; Sun, C.; Tan, L.; Liu, F. Integrated RNA Sequencing and QTL Mapping to Identify Candidate Genes from Oryza rufipogon Associated with Salt Tolerance at the Seedling Stage. Front. Plant Sci. $2017,8,1427$. [CrossRef] [PubMed]

65. Poonam, R.; Sunita, J.; Sheetal, Y.; Navinder, S.; Jain, R.K. Identification of SSR Markers for Salt-tolerance in Rice Variety CSR10 by Selective Genotyping. J. Plant Biochem. Biotechnol. 2009, 18, 87-91.

66. Chai, L.; Zhang, J.; Pan, X.; Zhang, F.; Zheng, T.; Zhao, X.; Wang, W.; Jauhar, A.; Xu, J.; Li, Z. Advanced Backcross QTL Analysis for the Whole Plant Growth Duration Salt Tolerance in Rice (Oryza sativa L.). J. Integr. Agric. 2014, 13, 1609-1620. [CrossRef]

67. Ren, Z.H.; Gao, J.P.; Li, L.G.; Cai, X.L.; Huang, W.; Chao, D.Y.; Zhu, M.Z.; Wang, Z.Y.; Luan, S.; Lin, H.X. A rice quantitative trait locus for salt tolerance encodes a sodium transporter. Nat. Genet. 2005, 37, 1141-1146. [CrossRef] [PubMed]

68. Riedelsberger, J.; Miller, J.K.; Valdebenito-Maturana, B.; Pineros, M.A.; Gonzalez, W.; Dreyer, I. Plant HKT Channels: An Updated View on Structure, Function and Gene Regulation. Int. J. Mol. Sci. 2021, 22, 1892. [CrossRef] [PubMed]

69. Gregorio, G.B. Tagging salinity tolerance genes in rice using amplified fragment length polymorphism (AFLP). Ph.D. Thesis, University of the Philippines, Los Banos, CA, USA, 1997; 118p.

70. Bonilla, P.; Dvorak, J.; Mackill, D.; Deal, K.; Gregorio, G. RFLP and SSLP mapping of salinity tolerance genes in chromosome 1 of rice (Oryza sativa L.) using recombinant inbred lines. Philipp. Agric. Sci. 2002, 65, 68-76.

71. Niones, J.; Gregorio, G.; Tumimbang, E. Fine mapping of the salinity tolerance gene on chromosome 1 of rice (Oryza sativa L.) using near isogenic lines. Crop Sci. Soc. Philipp. 2004, 31, 46.

72. Lan, T.; Zhang, S.; Liu, T.; Wang, B.; Guan, H.; Zhou, Y.; Duan, Y.; Wu, W. Fine mapping and candidate identification of SST, a gene controlling seedling salt tolerance in rice (Oryza sativa L.). Euphytica 2015, 205, 269-274. [CrossRef]

73. Ogawa, D.; Abe, K.; Miyao, A.; Kojima, M.; Sakakibara, H.; Mizutani, M.; Morita, H.; Toda, Y.; Hobo, T.; Sato, Y.; et al. RSS1 regulates the cell cycle and maintains meristematic activity under stress conditions in rice. Nat. Commun. 2011, 2, 278. [CrossRef]

74. Toda, Y.; Tanaka, M.; Ogawa, D.; Kurata, K.; Kurotani, K.; Habu, Y.; Ando, T.; Sugimoto, K.; Mitsuda, N.; Katoh, E.; et al. RICE SALT SENSITIVE3 forms a ternary complex with JAZ and class-C bHLH factors and regulates jasmonate-induced gene expression and root cell elongation. Plant Cell 2013, 25, 1709-1725. [CrossRef] [PubMed]

75. Deng, P.; Jiang, D.; Dong, Y.; Shi, X.; Jing, W.; Zhang, W. Physiological characterisation and fine mapping of a salt-tolerant mutant in rice (Oryza sativa). Funct. Plant Biol. 2015, 42, 1026-1035. [CrossRef]

76. Deng, P.; Shi, X.; Zhou, J.; Wang, F.; Dong, Y.; Jing, W.; Zhang, W. Identification and Fine Mapping of a Mutation Conferring Salt-Sensitivity in Rice (Oryza sativa L.). Crop Sci. 2015, 55, 219-228. [CrossRef]

77. Huang, X.; Feng, Q.; Qian, Q.; Zhao, Q.; Wang, L.; Wang, A.; Guan, J.; Fan, D.; Weng, Q.; Huang, T.; et al. High-throughput genotyping by whole-genome resequencing. Genome Res. 2009, 19, 1068-1076. [CrossRef] [PubMed] 
78. Yano, K.; Yamamoto, E.; Aya, K.; Takeuchi, H.; Lo, P.C.; Hu, L.; Yamasaki, M.; Yoshida, S.; Kitano, H.; Hirano, K.; et al. Genomewide association study using whole-genome sequencing rapidly identifies new genes influencing agronomic traits in rice. Nat. Genet. 2016, 48, 927-934. [CrossRef] [PubMed]

79. Ahmadi, N.; Negrão, S.; Katsantonis, D.; Frouin, J.; Ploux, J.; Letourmy, P.; Droc, G.; Babo, P.; Trindade, H.; Bruschi, G.; et al. Targeted association analysis identified japonica rice varieties achieving $\mathrm{Na}+\mathrm{K}+$ homeostasis without the allelic make-up of the salt tolerant indica variety Nona Bokra. Theor. Appl. Genet. 2011, 123, 881-895. [CrossRef] [PubMed]

80. Negrao, S.; Almadanim, M.C.; Pires, I.S.; Abreu, I.A.; Maroco, J.; Courtois, B.; Gregorio, G.B.; McNally, K.L.; Oliveira, M.M. New allelic variants found in key rice salt-tolerance genes: An association study. Plant Biotechnol. J. 2013, 11, 87-100. [CrossRef]

81. Cui, D.; Xu, C.; Yang, C.; Zhang, Q.; Zhang, J.; Ma, X.; Qiao, Y.; Cao, G.; Zhang, S.; Han, L. Association mapping of salinity and alkalinity tolerance in improved japonica rice (Oryza sativa L. subsp. japonica Kato) germplasm. Genet. Resour. Crop Evol. 2014, 62, 539-550. [CrossRef]

82. Li, B. Identification of Genes Conferring Plant Salt Tolerance using GWAS: Current Success and Perspectives. Plant Cell Physiol. 2020, 61, 1419-1426. [CrossRef]

83. Deolu-Ajayi, A.O.; Meyer, A.J.; Haring, M.A.; Julkowska, M.M.; Testerink, C. Genetic Loci Associated with Early Salt Stress Responses of Roots. iScience 2019, 21, 458-473. [CrossRef] [PubMed]

84. Cao, Y.; Zhang, M.; Liang, X.; Li, F.; Shi, Y.; Yang, X.; Jiang, C. Natural variation of an EF-hand Ca(2+)-binding-protein coding gene confers saline-alkaline tolerance in maize. Nat. Commun. 2020, 11, 186. [CrossRef] [PubMed]

85. Zhang, M.; Liang, X.; Wang, L.; Cao, Y.; Song, W.; Shi, J.; Lai, J.; Jiang, C. A HAK family Na+ transporter confers natural variation of salt tolerance in maize. Nat. Plants 2019, 5, 1297-1308. [CrossRef] [PubMed]

86. Kumar, V.; Singh, A.; Mithra, S.V.A.; Krishnamurthy, S.L.; Parida, S.K.; Jain, S.; Tiwari, K.K.; Kumar, P.; Rao, A.R.; Sharma, S.K.; et al. Genome-wide association mapping of salinity tolerance in rice (Oryza sativa). DNA Res. 2015, 22, 133-145. [CrossRef] [PubMed]

87. Zhang, Y.; Ponce, K.S.; Meng, L.; Chakraborty, P.; Zhao, Q.; Guo, L.; Gao, Z.; Leng, Y.; Ye, G. QTL identification for salt tolerance related traits at the seedling stage in indica rice using a multi-parent advanced generation intercross (MAGIC) population. Plant Growth Regul. 2020, 92, 365-373. [CrossRef]

88. Liu, C.; Chen, K.; Zhao, X.; Wang, X.; Shen, C.; Zhu, Y.; Dai, M.; Qiu, X.; Yang, R.; Xing, D.; et al. Identification of genes for salt tolerance and yield-related traits in rice plants grown hydroponically and under saline field conditions by genome-wide association study. Rice (NY) 2019, 12, 88. [CrossRef] [PubMed]

89. Batayeva, D.; Labaco, B.; Ye, C.; Li, X.; Usenbekov, B.; Rysbekova, A.; Dyuskalieva, G.; Vergara, G.; Reinke, R.; Leung, H. Genome-wide association study of seedling stage salinity tolerance in temperate japonica rice germplasm. BMC Genet. 2018, 19, 2. [CrossRef] [PubMed]

90. Neang, S.; de Ocampo, M.; Egdane, J.A.; Platten, J.D.; Ismail, A.M.; Seki, M.; Suzuki, Y.; Skoulding, N.S.; Kano-Nakata, M.; Yamauchi, A.; et al. A GWAS approach to find SNPs associated with salt removal in rice leaf sheath. Ann. Bot. 2020, 126, 1193-1202. [CrossRef]

91. Yu, J.; Zao, W.; He, Q.; Kim, T.S.; Park, Y.J. Genome-wide association study and gene set analysis for understanding candidate genes involved in salt tolerance at the rice seedling stage. Mol. Genet. Genom. 2017, 292, 1391-1403. [CrossRef] [PubMed]

92. Cui, Y.; Zhang, F.; Zhou, Y. The Application of Multi-Locus GWAS for the Detection of Salt-Tolerance Loci in Rice. Front. Plant Sci. 2018, 9, 1464. [CrossRef] [PubMed]

93. Lekklar, C.; Pongpanich, M.; Suriya-Arunroj, D.; Chinpongpanich, A.; Tsai, H.; Comai, L.; Chadchawan, S.; Buaboocha, T. Genome-wide association study for salinity tolerance at the flowering stage in a panel of rice accessions from Thailand. $B M C$ Genom. 2019, 20, 76. [CrossRef] [PubMed]

94. Yu, J.; Zhao, W.; Tong, W.; He, Q.; Yoon, M.Y.; Li, F.P.; Choi, B.; Heo, E.B.; Kim, K.W.; Park, Y.J. A Genome-Wide Association Study Reveals Candidate Genes Related to Salt Tolerance in Rice (Oryza sativa) at the Germination Stage. Int. J. Mol. Sci. 2018, 19, 3145. [CrossRef]

95. Rohila, J.S.; Edwards, J.D.; Tran, G.D.; Jackson, A.K.; McClung, A.M. Identification of Superior Alleles for Seedling Stage Salt Tolerance in the USDA Rice Mini-Core Collection. Plants 2019, 8, 472. [CrossRef]

96. Warraich, A.S.; Krishnamurthy, S.L.; Sooch, B.S.; Vinaykumar, N.M.; Dushyanthkumar, B.M.; Bose, J.; Sharma, P.C. Rice GWAS reveals key genomic regions essential for salinity tolerance at reproductive stage. Acta Physiol. Plant. 2020, 42, 134. [CrossRef]

97. Shi, Y.; Gao, L.; Wu, Z.; Zhang, X.; Wang, M.; Zhang, C.; Zhang, F.; Zhou, Y.; Li, Z. Genome-wide association study of salt tolerance at the seed germination stage in rice. BMC Plant Biol. 2017, 17, 92. [CrossRef] [PubMed]

98. An, H.; Liu, K.; Wang, B.; Tian, Y.; Ge, Y.; Zhang, Y.; Tang, W.; Chen, G.; Yu, J.; Wu, W.; et al. Genome-wide association study identifies QTLs conferring salt tolerance in rice. Plant Breed. 2019, 139, 73-82. [CrossRef]

99. Le, T.D.; Gathignol, F.; Vu, H.T.; Nguyen, K.L.; Tran, L.H.; Vu, H.T.T.; Dinh, T.X.; Lazennec, F.; Pham, X.H.; Very, A.A.; et al Genome-Wide Association Mapping of Salinity Tolerance at the Seedling Stage in a Panel of Vietnamese Landraces Reveals New Valuable QTLs for Salinity Stress Tolerance Breeding in Rice. Plants (Basel) 2021, 10, 1088. [CrossRef]

100. Li, N.; Zheng, H.; Cui, J.; Wang, J.; Liu, H.; Sun, J.; Liu, T.; Zhao, H.; Lai, Y.; Zou, D. Genome-wide association study and candidate gene analysis of alkalinity tolerance in japonica rice germplasm at the seedling stage. Rice (NY) 2019, 12, 24. [CrossRef] [PubMed] 
101. Li, X.; Zheng, H.; Wu, W.; Liu, H.; Wang, J.; Jia, Y.; Li, J.; Yang, L.; Lei, L.; Zou, D.; et al. QTL mapping and candidate gene analysis for alkali tolerance in Japonica rice at the bud stage based on linkage mapping and genome-wide association study. Rice (NY) 2020, 13, 48. [CrossRef] [PubMed]

102. Naveed, S.A.; Zhang, F.; Zhang, J.; Zheng, T.Q.; Meng, L.J.; Pang, Y.L.; Xu, J.L.; Li, Z.K. Identification of QTN and candidate genes for salinity tolerance at the germination and seedling stages in rice by genome-wide association analyses. Sci. Rep. $2018,8,6505$. [CrossRef]

103. Patishtan, J.; Hartley, T.N.; De Carvalho, R.F.; Maathuis, F.J.M. Genome-wide association studies to identify rice salt-tolerance markers. Plant Cell Environ. 2018, 41, 970-982. [CrossRef] [PubMed]

104. Yadav, A.K.; Kumar, A.; Grover, N.; Ellur, R.K.; Bollinedi, H.; Krishnan, S.G.; Bhowmick, P.K.; Vinod, K.K.; Nagarajan, M.; Singh, A.K. Genome-Wide association study reveals marker-trait associations for early vegetative stage salinity tolerance in rice. Plants (Basel) 2021, 10, 559. [CrossRef] [PubMed]

105. Yuan, J.; Wang, X.; Zhao, Y.; Khan, N.U.; Zhao, Z.; Zhang, Y.; Wen, X.; Tang, F.; Wang, F.; Li, Z. Genetic basis and identification of candidate genes for salt tolerance in rice by GWAS. Sci. Rep. 2020, 10, 9958. [CrossRef] [PubMed]

106. Julkowska, M.M.; Koevoets, I.T.; Mol, S.; Hoefsloot, H.; Feron, R.; Tester, M.A.; Keurentjes, J.J.B.; Korte, A.; Haring, M.A.; de Boer, G.J.; et al. Genetic components of root architecture remodeling in response to salt stress. Plant Cell 2017, 29, 3198-3213. [CrossRef] [PubMed]

107. Neeraja, C.N.; Mishra, B.; Rao, K.S.; Singh, R.K.; Padmavati, G.; Shenoy, V.V. Linkage disequilibrium in salt tolerant genotypes of rice (Oryza sativaL). J. Plant Biochem. Biotechnol. 2008, 17, 65-68. [CrossRef]

108. Al-Tamimi, N.; Brien, C.; Oakey, H.; Berger, B.; Saade, S.; Ho, Y.S.; Schmockel, S.M.; Tester, M.; Negrao, S. Salinity tolerance loci revealed in rice using high-throughput non-invasive phenotyping. Nat. Commun. 2016, 7, 13342. [CrossRef]

109. Li, X.; Zheng, H.; Zhao, H.; Wang, J.; Liu, H.; Sun, J.; Li, N.; Lei, L.; Zou, D. Association analysis of saline-alkali related traits and SSR markers in Japonica rice under soda saline-alkali stress. Acta Agric. Boreali-Sin. 2018, 33, 139-148.

110. Huang, X.; Wei, X.; Sang, T.; Zhao, Q.; Feng, Q.; Zhao, Y.; Li, C.; Zhu, C.; Lu, T.; Zhang, Z.; et al. Genome-wide association studies of 14 agronomic traits in rice landraces. Nat. Genet. 2010, 42, 961-967. [CrossRef]

111. Xie, L.; Zheng, C.; Li, W.; Pu, M.; Zhou, G.; Sun, W.; Wu, X.; Zhao, X.; Xie, X. Mapping and identification a salt-tolerant QTL in a salt-resistant rice landrace, Haidao86. J. Plant Growth Regul. 2021. [CrossRef]

112. Das, P.; Nutan, K.K.; Singla-Pareek, S.L.; Pareek, A. Understanding salinity responses and adopting 'omics-based' approaches to generate salinity tolerant cultivars of rice. Front. Plant Sci. 2015, 6, 712. [CrossRef] [PubMed]

113. Bimpong, I.K.; Manneh, B.; Sock, M.; Diaw, F.; Amoah, N.K.A.; Ismail, A.M.; Gregorio, G.; Singh, R.K.; Wopereis, M. Improving salt tolerance of lowland rice cultivar 'Rassi' through marker-aided backcross breeding in West Africa. Plant Sci. 2016, 242, 288-299. [CrossRef]

114. Lakra, N.; Nutan, K.K.; Das, P.; Anwar, K.; Singla-Pareek, S.L.; Pareek, A. A nuclear-localized histone-gene binding protein from rice (OsHBP1b) functions in salinity and drought stress tolerance by maintaining chlorophyll content and improving the antioxidant machinery. J. Plant Physiol. 2015, 176, 36-46. [CrossRef] [PubMed]

115. Soda, N.; Kushwaha, H.R.; Soni, P.; Singla-Pareek, S.L.; Pareek, A. A suite of new genes defining salinity stress tolerance in seedlings of contrasting rice genotypes. Funct. Integr. Genom. 2013, 13, 351-365. [CrossRef] [PubMed]

116. Kumari, S.; Nee Sabharwal, V.P.; Kushwaha, H.R.; Sopory, S.K.; Singla-Pareek, S.L.; Pareek, A. Transcriptome map for seedling stage specific salinity stress response indicates a specific set of genes as candidate for saline tolerance in Oryza sativa L. Funct. Integr. Genom. 2008, 9, 109-123. [CrossRef] [PubMed]

117. Singh, R.; Singh, Y.; Xalaxo, S.; Verulkar, S.; Yadav, N.; Singh, S.; Singh, N.; Prasad, K.S.N.; Kondayya, K.; Rao, P.V.R.; et al. From QTL to variety-harnessing the benefits of QTLs for drought, flood and salt tolerance in mega rice varieties of India through a multi-institutional network. Plant Sci. 2016, 242, 278-287. [CrossRef] [PubMed]

118. Singh, A.K.; Gopalakrishnan, S.; Singh, V.P.; Prabhu, K.V.; Mohapatra, T.; Singh, N.K.; Sharma, T.R.; Nagarajan, M.; Vinod, K.K.; Singh, D.; et al. Marker Assisted Selection: A paradigm shift in Basmati breeding. Indian J. Genet. Plant Breed. 2011, 71, 120-128.

119. Linh le, H.; Linh, T.H.; Xuan, T.D.; Ham le, H.; Ismail, A.M.; Khanh, T.D. Molecular breeding to improve salt tolerance of rice (Oryza sativa L.) in the red river delta of Vietnam. Int. J. Plant Genom. 2012, 2012, 949038. [CrossRef]

120. Gregorio, G.; Islam, R.; Vergara, G.; Thirumeni, S. Recent advances in rice science to design salinity and other abiotic stress tolerant rice varietie. SABRAO J. Breed. Genet. 2013, 45, 31-41. 